Original Contribution

\title{
LARGER FUNGI - INDICATOR SPECIES FOR XEROTHERMIC GRASSLANDS OF PROTECTED AREA "SHEEP HILLS" THRACIAN LOWLAND (BULGARIA)
}

\author{
M. Lacheva* \\ Department of Botany and Agrometeorology, Agricultural University, Plovdiv, Bulgaria
}

\begin{abstract}
In the Protected Area "Sheep Hills", xerothermic grasslands are semi-natural habitats developed on old volcanic and limestone hills. Xerothermic grassland belongs to the class Thero-Brachypodietea, and the alliances Thero-Brachypodion and Astragalo-Poion bulbosae. The xerothermic grasslands have their own characteristic mycota, as following steppe, xerothermic, and thermophilous fungi deserve special attention: Agaricus bernardii, A. comtulus, A. maleolens, Crinipellis mauretanica, Entoloma incanum, Hygrocybe virginea, H. persistens, Lepiota erminea, Leucopaxillus lepistoides, Tulostoma fimbriatum, and T. volvulatum. The studyfound the occurrence of 6 fungi included in the Bulgarian Red List of fungi and the Red Data Book in the Republic of Bulgaria - Amanita vittadinii, Crinipellis mauretanica, Geastrum melanocephalum, Myriostoma coliforme, Tulostoma fimbriatum, and T. volvulatum. The main factors threatening xerothermic grasslands of the Sheep Hills area, among others, the devastation and disappearance of natural habitats, often as a result of in appropriate land management as well as the pollution of air, water, and soil.

The aim of the paper is to enrich the information about larger fungi indicator species for xerothermic grasslands in this protected area and the country.
\end{abstract}

Key words: Protected Area "Sheep Hills", xerothermic grasslands, larger fungi, semi-natural habitats, Thero-Brachypodietea, steppe fungi, xerothermic fungi

\section{INTRODUCTION}

The Protected Area "Sheep Hills" is situated in the Thracian Lowland region, in the land of village of Ovchepoltsi, Pazardzhik municipality, Plovdiv distr., close to the Pazardzhik town. The climate is transitional continental (1). Summers are warm and winters are mild and moderately cold, without lasting snow cover and withsmall temperature amplitudes.

According to the physical and geographical regionalisation, the mountain is situated within the Thrace region $(2,3)$. The highest peak in the Sheep Hills is mainly constitutes of old and e site and volcanic rocks, with some limestone out crops. Soil cover in the Protected Area is represented by shallow leached and

*Correspondence to: Maria Lacheva, Department of Botany and Agrometeorology, Agricultural, University-Plovdiv, 12, Mendeleev Str., 4000 Plovdiv, Bulgaria,e-mail: agaricus@abv.bg podzolized cinnamon-forest soils. The predominant soil types are cinnamon-podzolic soils (4).

The protected area is included in the national Natura 2000 Network, with the sole purpose of protecting the natural habitat and maintain representative ecosystem for eastern subMediterranean dry grasslands, eastern forests of Quercus pubescens and pseudo-steppe with grasses and annuals of the TheroBrachypodietea; (BG0000365, Protected area according to Directive 92/43/EECfor conservation of natural habitats and of wild fauna and flora). This is the first mycological study conducted on the territory of this interesting area. Data from this study in the Sheep Hills provide information on the fungi indicator species in the xerothermic grasslands in Bulgaria. 
The Protected Area "Sheep Hills" can be characterized by the presence of volcanic and limestone hills. Xerothermic grasslands developed on slopes of these hills are seminatural habitats. The development of xerothermic grasslands was strictly connected with agricultural and pastoral farming of man. Typical representatives of the herbaceous plants are Aegilops neglecta, A. geniculata, Bromus fasciculatus, B. madritensis, B. intermedius, Bothriochloa ischaemum, Brachypodium distachyon, Chrysopogon gryllus, Cynodon dactylon, Cynosurus echinatus, Dactylis glomerata, Dichanthium ischaemum, Eryngium campestre, Knautia orientalis, Medicago minima, M. rigidula, Poa bulbosa, Salvia viridis, Trifolium echinatum, $T$. purpureum, $T$. subterraneum, Xeranthemum annuиm, etc.). These grasses belong to the class TheroBrachypodietea and the alliances Thero Brachypodion, Astragalo-Poion bulbosae, Trachynion distachya and Xeranthemion annui.

The larger fungi in xerothermic grasslands in Bulgaria are poorly known. A summary over view of macromycetes in Mediterranean and sub-Mediterranean plant communities in the country provides (5). The importance of this problem stems from the fact that knowledge and literature on fungi associated with thermophilous and xerothermic grasslands in Europe and Bulgaria are still very inadequate (5-22).

In recent years, many changes in the xerothermic grassland communities of the Protected Area "Sheep Hills" have been observed. These changes may lead to the disappearance of rare plants as well as whole phytocoenoses of an extreme interest.

The xerothermic grasslands have their own mycota characteristic for them. The aim of the investigations was to identify resources of larger fungi growing in the xerothermic grasslands ofthe study area and to distinguish indicator species for them. The collected scientific information will be used for analysis and planning activities on the conservation and management of the biodiversity in the protected territory in the future.

\section{MATERIALS AND METHODS}

The current research is based on observationsand collection of larger fungi in the xerothermic grasslands of the Protected Area "Sheep Hills" between 2010-2012. The study was carried out in 12 permanent plots with size $1000 \mathrm{~m}^{2}$ each distributedin the communities belonging to the class Thero-Brachypodietea. Collection of fruit bodies was carried out each year from AprilOctober. Furthermore, fungi were also collected outside the permanent study plots, using socalled the itinerary method, which allowed us to enrich observations and to gather data concerning the composition of larger fungi species growing in the xerothermic grasslands.

To illustrate the floristic composition and existing phytosociological relationships in the investigated phytocoenoses, phytosociological study were performe dusing the (23) method. The nomenclature for fungi is according to (24), vascular plants according to (25), and plant communities according to (26) and (27). The author's names of the fungal taxa are abbreviated according to (28). Identification and nomenclature of the specimens was performed according to (29-45). The conservation status is indicated according to the Red List of fungi in Bulgaria (46).

Studied specimens are kept in the Agricultural University (SOA) in Plovdiv; their accession numbers are given in brackets atthe end of each record. Specimens were collected by the author, unless other wise stated.

The identification of the collected material was done in two stages. In the first stage, if it was possible, fruit bodies were identified in fresh samples, while during the second stage identification was performed after fruit bodies had been dried. Microscopic features are observed and measured in lactophenol under an Amplival ML light microscope, with magnification $\times 1000$.

\section{RESULTS AND DISCUSSION}

Changes taking place in the plant communities have a strong influence on the species composition of fungi $(11,22)$.

During the course of the investigations on the mycobiota of the Sheep Hills xerothermic grasslands, the occurrence of more than 46 species of larger fungi belonging to the classes Agaricomycetes was established. From among this group, 36 species were selected which were identified, based on their general distribution and habitat requirements, to be distinctly connected with the xerothermic grasslands. These species can be considered to be indicative of this type of habitats (Table 1). 
Table 1. List of larger fungi species from xerothermic grasslands in the Protection Area "Sheep Hills"

\begin{tabular}{|c|c|}
\hline Species of larger fungi & $\begin{array}{c}\text { Plant alliances in which the occurrence of } \\
\text { larger fungi was confirmed }\end{array}$ \\
\hline Agaricus arvensis Schaeff. & Astragalo-Poion bulbosae, Trachynion distachya \\
\hline A. bernardii Quél. & Astragalo-Poion bulbosae \\
\hline A. comtulus Fr. & Astragalo-Poion bulbosae, Trachynion distachya \\
\hline A. cupreobrunneus (F.H. Møller) Pilát & Astragalo-Poion bulbosae \\
\hline A. campestris L. : Fr. & Thero-Brachypodion, Trachynion distachya \\
\hline A. maleolens F.H. Møller & Astragalo-Poion bulbosae \\
\hline A. xanthodermus Genev. & Thero-Brachypodion, Trachynion distachya \\
\hline Agrocybe molesta (Lasch) Singer & Astragalo-Poion bulbosae \\
\hline Amanita vittadinii (Moretti) Vittad. & Astragalo-Poion bulbosae, Trachynion distachya \\
\hline Bovista plumbea Pers. : Pers. & Thero-Brachypodion, Trachynion distachya \\
\hline Conocybe apala (Fr. : Fr.) Arnolds & Astragalo-Poion bulbosae \\
\hline Coprinus comatus (O.F. Müll. : Fr.) Pers. & Thero-Brachypodion, Trachynion distachya \\
\hline Crinipellis mauretanicaMaire & Thero-Brachypodion \\
\hline C. scabella (Alb. \& Schwein. : Fr.) Murrill & Thero-Brachypodion \\
\hline Cyathus olla (Batsch. : Pers) Pers & Astragalo-Poion bulbosae, Trachynion distachya \\
\hline Entholoma incanum (Fr. : Fr.) Hesler & Thero-Brachypodion \\
\hline Geastrum fornicatum (Huds.) Hook. & Thero-Brachypodion, Trachynion distachya \\
\hline G. melanocephalum (Czern.) V.J. Staněk & Thero-Brachypodion \\
\hline G. rufescens Pers. : Pers. & Thero-Brachypodion \\
\hline Hygrocybe miniata (Fr. : Fr.) P. Kumm. & Astragalo-Poion bulbosae \\
\hline H. persistens (Britzelm.) Singer & Thero-Brachypodion \\
\hline H. virginea (Wulfen : Fr.) P.D. Orton \& Watling & Astragalo-Poion bulbosae, Trachynion distachya \\
\hline Leucopaxillus lepistoides (Maire) Singer & Thero-Brachypodion \\
\hline Lepiota erminea (Fr. : Fr.) P. Kumm. & Thero-Brachypodion, Trachynion distachya \\
\hline Marasmius oreades (Bolton : Fr.) Fr. & Thero-Brachypodion, Trachynion distachya \\
\hline Macrolepiota excoriata (Schaeff. : Fr.) Wasser & Astragalo-Poion bulbosae,Trachynion distachya \\
\hline M. procera (Scop. : Fr.) Singer & Thero-Brachypodion \\
\hline Panaeolus sphinctrinus (Fr.) Quél. & Thero-Brachypodion, Trachynion distachya \\
\hline Pleurotus eryngii (DC. : Fr.) Quél. & Thero-Brachypodion, Trachynion distachya \\
\hline Stropharia coronilla (Bull. : Fr.) Fr. & Thero-Brachypodion, Trachynion distachya \\
\hline S. semiglobata (Batsch. : Fr.) Qéll. & Astragalo-Poion bulbosae \\
\hline Tulostoma brumale Pers. : Pers. & Thero-Brachypodion, Trachynion distachya \\
\hline T. fimbriatum Fr. & Thero-Brachypodion \\
\hline T. volvulatum I.G. Borshch. & Thero-Brachypodion \\
\hline Vascellum pratense (Pers. : Pers.) Kreisel & Thero-Brachypodion, Trachynion distachya \\
\hline
\end{tabular}


The analysis of the macromycetes species composition of the studied grasslands belonging to the class Thero-Brachypodietea reveals its uniqueness. Of particular importance are the steppe, xerothermic, and thermophilous fungi whose presence underline the mycological relationship with the plant communities belongingto the alliance Thero-Brachypodion, and these are as follows: Entoloma incanum, Hygrocybe persistens, Lepiota alba, and Leucopaxillus lepistoides, although latter has the most out standing features considered to be a typical steppe species $(10,11,19,22)$. The occurrence of typical steppic species of macromycetes is very rare in Bulgaria. Additionally, other interesting fungi connected with the Astragalo-Poion bulbosae grasslands are Agaricus bernardii, A. cupreobrunneus, and Hygrocybe virginea $(22,47)$. A characteristic feature of the grassland mycobiota in this area is the occurrence of calciphilous fungi that include, among others Bovista plumbea, Entoloma incanum, Lepiota alba, Leucopaxillus lepistoides, Geastrum minimum, and Tulostoma fimbriatum, which can beconsidered to be a characteristic species for the xerothermic grasslands $(11,30)$.

Equally interesting and rare is Agaricus maleolens, a species that is associated with xerothermic grasslands (30). Basidiomata of Crinipellis mauretanica develop on rotten sticks in grassy placesand of Crinipellis scabella occuron a largely degree on dry grass blades $(21$, 48-50). Fruit bodies of Stropharia coronilla, Marasmius oreades, Pleurotus eryngii and Vascellum pratense also occur in vast numbers. These are fungi with a wide range of occurrence, mostly in the grasslandsin question, but also in psammophilous grassland, and in dry pine forests $(11,22)$.

The fungi associated with dry and warm habitats are the most interesting. These fungi belong to extremely specialised thermophilous and calciphilous organisms whose development is possibleonly in deforested and open xerothermic communities (22). A separate group comprises of fungi more often growing in the meadows and pastures, including among others Agaricus arvensis, A. campestris,A. xanthodermus, Cyathus olla, Hygrocybe virginea, Macrolepiota excoriata and $M$. procera which are also present intoxerothermic grasslands. Were observed and some mushrooms developing on excrement, namely Coprinus comatus, Panaeolus sphinctrinus, and Stropharia semiglobata.
The habitats of the Sheep Hills xerothermic grasslands are the place of occurrence of many interesting macromycetes species, some of which are consideredas rare and threatened both in Bulgaria and Europe. The study found the occurrence of 6 fungi being on the Bulgarian Red List of fungi (46) and Red Data Book in the Republic of Bulgaria (51) which are as follows: Amanita vittadinii, Crinipellis mauretanica, Geastrum melanocephalum, Myriostoma coliforme, Tulostoma fimbriatum, and $T$. volvulatum.

\section{CONCLUSION}

The effective protection of many plant species and macromycetes is only possible by protecting their entire semi-natural habitats, and not only their single components.

The achieved results have a significant importance for the identification of macromycetes biota growing in rare ecosystems in the communities belonging to the class TheroBrachypodietea withinthe investigated area. The knowledge of selected fungi, which can be considered to have diagnostic features, allows us to use these organisms for bioindication of their habitats. This is of particularly great significance during the preparation of conservations plans for nature reserves and protected areas as well as during the evaluation of negative impacts on the environment.

Hope that this study will enrich information about fungal diversity of the Protected Area "Sheep Hills" as well as for the fungal diversity to xerothermic grasslands in Bulgaria, on the whole.

\section{REFERENCES}

1. Velev, S. Climatic regionalization. In: Geography of Bulgaria. Physical geography. Socio-economic geography. For Com Publ. House, pp. 155-157, 2002.

2. Georgiev, M., Physical Geography of Bulgaria. Science and Art Publishing House, Sofia, p. 406, 1985 (Bg).

3. Yordanova, M., Velev, S., Drenovski, I., Characteristic features of the physical geographical regions. In: Geography of Bulgaria. Physical geography. Socioeconomic geography., For Com Publ. House, pp. 409-411, 2002.

4. Ninov, N., Soil-geographic Regions. In: Geography of Bulgaria. I. Sofia, 397-405, $1982(\mathrm{Bg})$.

5. Gjoševa, M., Macromycetes in Mediterranean and submediterranean plant 
communities of Bulgaria: a check list. Bocconea 5: 873-876, 1997.

6. Vasilkov, B.P., About steppe mushrooms Agaricus bernardii (Quél.) Sacc. Botanical Materials spore plants, 9: 154-157, 1953.

7. Wasser, S.P., Soldatova, I.M., Higher Basidiomycetes steppe zone of Ukraine. Naukova Dumka, Kiev, p. 319, 1977.

8. Winterhoff, W., Zur Pilzflora der fraenkischen Gipshügel. Jahresmitteilungen der Naturhistorischen Gesellschaft Nuernberg. Nuernberg, 81-85, 1986 (in German).

9. Winterhoff, W., Grosspilze in Kalktrockenrasen der südwestdeutschen Tieflagen. Carolinea 53: 251-258, 1995 (in German).

10. Hinkova, Ts., Stoichev, G. Leucopaxillus lepistoides (Maire) Sing. in Bulgaria. In: V. Velchev [ed.]. Third National Conference of Botany, Sofia, 26-30.X.1981, pp.39-41. Bulgarian Academy of Sciences Publishing House, Sofia, 1983 (Bg).

11. Droumeva-Dimcheva, M., GyoshevaBogoeva, M., Macromycetes in Bulgaria, pp. 34, 1993 (Bg).

12. Lizoň, $P$, Macrofungi reported as extinct/missing orthreatened with extinction in European Red Data Lists. Fungi and Conservation Newsletter 3, September, 1995.

13. Jordal, J.B., Hygrocybe and Cuphophyllus as ecological indicators. IMC 7. Book of Abstracts: 46. The 7th International Mycological Congress, Oslo, 11-17 August, 2002.

14. Laganá, A., Salerni, E., Barluzzi, C., Dominicis, V. and Perini, C., Fungi (Macromycetes) in various types of Mediterranean forest ecosystems (Tuscany, Italy). Polish Botanical Journal, 47(2): 143165, 2002.

15. Dahlberg, A., Croneborg, H. (eds).,33 threatened fungi in Europe. Complementary and revised information on candidates for listing in Appendix I of the Bern Convention. T-PVS document (2001) 34 rev. 2. Council of Europe, Strasbourg, 2003.

16. Newton, A.C., Davy, L.M., Holden, E., Silver-side, A., Watling, R., Ward, S.D., 2003. Status, distribution and definition of mycologically important grasslands in Scotland. Biological Conservation,111: 1123.

17. Zervakis, G., Dimou, D.M. and Polemis, E., Fungal diversity and conservation in the
Mediterranean area: Recent advances in the inventory of Greek macromycetes. Mycologia Balcanica, 1: 31-34, 2004.

18. Stasińska, M., The state of knowledge of Macromycetesin xerothermic grasslands in Poland. Ann. UMCS, Biologia, 63(1): 7178, 2008.

19. Łuszczyński, J., Leucopaxillus lepistoides a new steppe fungus in Poland. Acta Mycologica, 41(2): 279-284, 2006.

20. Senn-Irlet, B., Heilmann-Clausen, J., Genney, D., Dahlberg, A., Guidance for Conservation of Macrofungi in Europe. October 2007. Document prepared for The Directorate of Culture and Cultural and Natural Heritage Council of Europe, Strasbourg, p. 39, 2007.

21. Łuszczyński, J., Łuszczyńska, B., Steppe macromycetes in xerothermic grasslands in Poland. [In:] Grass research. L. Frey (ed.). W. Szafer Institute of Botany, Polish Academy of Sciences, Kraków: 119-127, 2009.

22. Jaworska, J., Łuszczyński, J., Łuszczyńska, B. and Tomaszewska, A., Macromycetes indicator species for xerothermic grasslands of the Chęciny district. Acta Agrobotanica, 65(1): 63-70, 2012.

23. Braun-Blanquet, J., $1964 . \quad$ Pflanzen soziologie, Wien-NewYork.

24. Denchev CM, Assyov B. Checklist of the larger basidiomycetes in Bulgaria. Mycotaxon, 111: 279-282, 2010.

25. Delipavlov, D., Popova, M., Kovachev, I., Terziyski, D., Cheshmedjiev, I., The Plants in Bulgaria, Zemizdat, 2003.

26. Bondev, I.,Vegetation in Bulgaria - map 1:600000 with explanatory text, University Press "St. Kliment Ohridski", Sofia, 1991 (Bg).

27. Kavrakova, V., Dimova, D., Dimitrov, M., Conev, R., Belev, T., Rakovska, K. /red./. Guidance for identifying habitats of European importance in Bulgaria. Second, revised edition. Sofia, World Wildlife Fund, Danube-Carpathian Programme and the Federation"GREEN BALKANS", 2009.

28. Kirk, P.M., Ansell, A.E. Authors of Fungal Names. Electronic version. CABInternational, Wallingfort (www.indexfungorum.org/Names), 2004.

29. Arnolds, E., Ecology and coenology of macrofungi in grasslands and moist heathlands in Drenthe, the Netherlands, 1. J. Cramer, 1981. 
30. Cappelli, A., Fungi Europaei, AgaricusL. : Fr. (PsalliotaFr.). Saronno, 1984.

31. Clémençon, H., Kompendium der Blätterpilze VI. Laccaria. Zeitschrift für Mykologie, 50: 3-12, 1984.

32. Courtecuisse, R., Duhem, B., Collins Field Guide. Mushrooms and toadstools of Britain and Europe. Harper Collins Publishers, London, 1995.

33. Contu, M., Il genere Laccaria (Basidiomycotina, Agaricales) in Italia, con note sulle rimanenti specie in Europa. Bollettino del Gruppo Mycologico $G$. Bressadola - NuovaSerie, 46(1): 5-58, 2003.

34. Dennis, R.W.G., British Ascomycetes. 2nd ed. J. Cramer, Vaduz, 1978.

35. Dissing, H., Geopora Harkness. In: Hansen, L. \& Knudsen, H. (eds). Nordic Macromycetes. Vol. 1. Ascomycetes. Nordsvamp, Kopenhagen, pp. 97-98. 2000.

36. Moser, M., Die Rohrlinge and Blatterpilze. Vol. 2b/2. Basidiomyceten. Teil (Agaricales). Stuttgart. New York, Veb. G. Fischer Verlag, p. 443, 1967.

37. Moser, M., Röhrlinge und Blätterpilze. 4 thed. Kleine Kryptogamen flora Mitteleuropas. Vol. 2b/2. G. Fischer Verlag, Stuttgart, 1978.

38. Moser, M., Key Agarics and Boleti (Polyporales, Boletales, Agaricales, Russulales), 1983.

39. Phillips, R. 1981. Mushrooms and Other Fungi of Great Britain and Europe. Pan Books Ltd. pp. 287, 1981.

40. Hansen, L., Knudsen, H. Nordic Macromycetes. Vol. 2. Polyporales, Boletales, Agaricales, Russulales. Helsinki University Printing House, Helsinki, 1992.

41. Galli, R., Le Russule. Atlantepraticomonografico perla determinazione delle russule. Edinatura, p. 480, 1996.

42. Neville, P., Poumarat, S., Amaniteae. In: Fungi Europaei. Vol. 9. Edizioni Candusso, Alassio, p.1120, 2004.
43. Sunhede, S., Geastraceae. Morphology, ecology, and systematics with special emphasis on the North Europaean species. Synopsis Fungorum 1. Fungi flora-OsloNorway, p. 534, 1989.

44. Wasser, S. Biodiversity of Cyanoprocaryotes, Algae and Fungi of Israel. Family Agaricaceae (Fr.) Cohn. (Basidiomycetes) of Israel Mycobiota. I. Tribe Agariceae Pat. Ruggell, 2002.

45. Watling, R. Identification of the Larger Fungi. Amersham: Walton. 281 p., 1973.

46. Gyosheva, M.M., Denchev, C.M, Dimitrova, E.G., Assyov, B., Petrova, R.D. and Stoichev, G.T., Red List of Fungi in Bulgaria. Mycologia Balcanica,3(1):81-87, 2006.

47. Lacheva, M. Genus Agaricus L.: Fr. emend. P. Karst. (mushroom) in Bulgaria taxonomy, ecology, chorology and economical importance. $\mathrm{PhD}$ thesis, AgriculturalUniversity-Plovdiv, Bulgaria. [http://botanica.hit.bg/doc/AgaricusPhDthes is.pdf], 2006.

48. Assyov, B., Stoykov, D.Y., Gyosheva, M., Some rare and noteworthy larger fungi in Bulgaria. Trakia Journal of Sciences, 10(2): 1-9, 2012.

49. Kujawa, A., Wrzosek, M., Domian, G., Kedra, K., Szkodzik, J., Rudawska, M., Leski, T., Karlinski., Pietras, M., Gierczyk, B., Dinowska, M., Slusarczyk, D., Kałucka, I., Ławrinowicz, M., Preliminary studies of fungi in the Biebrza National Park (NE Poland). II. Macromycetes. Acta Mycologica, 47(2): 235-264, 2012.

50. Lacheva, M. New data for some rare macromycetes in Bulgaria. Agricultural Science and Technologies, 4(4): 434-439, 2012.

51. Peev, D. et al., Red Data Book in the Republic of Bulgaria. Vol. 1. Plant and Fungi. IBEI- BAS \& MOEW, Sofia, 2011. 